\title{
Physiological and Agronomic Responses of Four Rice Varieties to Drought in the Rainforest
}

\author{
Mamadou FOFANA ${ }^{1}$, Olalekan Suleiman SAKARIYAWO ${ }^{2 *}$, \\ Mauton Oluwaseun POPOGBE², Akeem Abdulahi OYEKANMI², \\ Jamiu Oladipupo AZEEZ ${ }^{3}$, Felix Taiwo ADEGBEHINGBE ${ }^{1}$ \\ ${ }^{1}$ Africa Rice Centre, Ibadan Sub-station, Nigeria \\ ${ }^{2}$ Federal University of Agriculture, Abeokuta (FUNAAB), Department of Plant Physiology and Crop Production, \\ P.M.B.2240, Alabata, Nigeria; adetanwa@yahoo.co.uk ("corresponding author) \\ ${ }^{3}$ FUNAAB, Department of Soil Science and Land Management, P.M.B 2240, Alabata, Nigeria
}

\begin{abstract}
The present investigation tested the hypothesis that there would be variation in physiological responses to water deficit among rice varieties from different production ecologies, with contrasting tolerance to water deficit under repeated cycle of soil moisture deficit, at reproductive growth stage. A screen house and a field trial were conducted at International Institute of Tropical Agriculture, Ibadan and Ikenne (Latitude $6^{\circ} 52^{\prime} \mathrm{N}$, Longitude $3^{\circ} 43^{\prime} \mathrm{E}$ ) respectively. Both experiments had rice varieties ('IR 64', 'WAB 56-104', 'IR 77298-1-2-B-10' and 'NERICA 4') and stress status (stress and control) as treatment factor's, arranged in a randomised complete block design with three replicates. In both trials, the physiological mechanism that underpins varietal differences with repeated cycles of water deficit at the reproductive growth stage was more balanced water status, improved foliar characters, efficient photosynthetic capacity and higher grain yield in comparatively drought tolerant upland rice varieties ('NERICA 4' and 'WAB 56-104'), as opposed with the results for the drought susceptible cultivar 'IR 64'. A converse pattern was observed on water stressed rice, despite fewer cycles of water deficit on the field. The results could have suggested that the initiation of water deficit is the rate limiting step rather than its intensity at the reproductive growth stage.
\end{abstract}

Keywords: foliar character; grain yield; physiological responses; production ecology; soil moisture deficit

\section{Introduction}

There has been a great concern on the implication of climate change on agricultural production in recent past. This is even more germane when examined in the context of the implications of climate change on the agricultural productivity of the most vulnerable part of the world such as Africa and Asia, where agricultural production is predominantly extensive in nature with low agricultural input. It had been observed that climate change could result in an increase in temperature and changes in rainfall distribution (Parry, 2007).

The combined effects of these factors could constrain agricultural production especially among resource challenged farmers in the Sub-Sahara Africa (SSA). Moisture stress is capable of creating disequilibrium in crop water balance, subsequently affecting yield. Diagne et al. (2013) reported that biophysical constraints were perceived by farmers to have accounted for $30 \%$ of the constraints in rice production in SSA. They also reported that in upland rice production, $35 \%$ of this yield constraints could be attributed to drought alone. These biophysical constraints increased poverty and reduced income generation among rice farming communities (Diagne et al., 2013). Rice as a cereal is becoming more popular in SSA due to its ease of preparation (Diagana et al., 1999) and changes in the demographic profile of the populace (Idris et al., 2013). The demand for rice among the populace could not be met by local production in Nigeria in recent past due in part to earlier highlighted factors. By implication more nations in SSA have resulted into massive importation of rice from other countries that could have negative effect on their balance of payment in the face of dwindling foreign exchange earnings. Both upland and lowland rice are known to be susceptible to drought, but relatively tolerant to water logging (Grzesiak et al., 2016). Comparatively, farmers prefer to cultivate lowland rice than the upland rice due to their productivity. With shortages in available fresh water 
supply that could pose a big challenge in the long run, cultivation of upland land remains the other option, whereas provided challenges posed by abiotic stress would be properly addressed.

Centritto et al. (2009) conducted a study to explicate physiological responses of rice varieties from different production ecologies with contrasting susceptibilities to soil water deficit at reproductive growth stage. Results from that investigation suggested that photosynthetic capacity and performances of those rice varieties were constrained majorly by diffusion of $\mathrm{CO}_{2}$ into the leaf prior to biochemical limitations on carbon assimilation. However, there is little information on the physiological and agronomic implication of repeated cycle of water deficit and recovery at reproductive growth stage on rice from different production ecologies with contrasting drought tolerance in the rainforest.

Efforts had been made by Africa Rice towards the improvement of rice cultivars, in most rice growing areas of Africa. This had led to the introduction of New Rice for Africa (NERICA) (Wopereis et al., 2008). These are interspecific hybrids that combined the hardiness of Oryza glabberima with high yield of Oryza sativa. They have been reported to be more drought tolerant than the existing rice cultivars (Jones et al., 1997). However, performance of NERICA rice from different production ecologies under repeated water stressed conditions has not been fully explored in the literature. Efforts had been made in the past to physiologically characterize the mechanisms that underpin these drought tolerant rice cultivars. It was established that their superior performance could be based upon their hydraulic properties, such as improved rate of transpiration and better root hydraulic conductance compared with the susceptible rice cultivars (Henry et al., 2012; Henry et al., 2015). This could have suggested that there was no conservative use of water. Grain yield is not only a function of the diffusive properties of rice, but on the efficiency of conversion and partitioning of assimilates to the reproductive structures especially at the grain filling growth stage (Tardieu, 2013).

It was thus tested the hypothesis that there would be variation in physiological response to water deficit by rice varieties from different production ecologies with contrasting drought tolerance under repeated cycle of soil moisture deficit at reproductive growth stage. It was examined the hypothesis that this physiological variation would result in differences in grain yield among the rice varieties under this condition. The present study was carried out with the aim of explicating the physiological basis of drought tolerance among rice cultivars from different rice production agroecologies subjected to repeated cycle of soil moisture stress at reproductive growth stage. Understanding the physiological basis for this variation would aid the breeders in crop improvement under different production ecologies.

\section{Materials and Methods}

\section{Screen house experiment}

An open screen house and a field trial were conducted. The open screen house was protected from rainfall and dew through erection of an artificial rainout shelter; hence the climate condition was similar to the ambient obtainable during the cropping season. The trials were conducted at the International Institute of Tropical Agriculture (IITA), Ibadan (Latitude 7o 30' 8" $\mathrm{N}$ and Longitude $3^{\circ} 54^{\prime} 37^{\prime \prime} \mathrm{E}$ ), Oyo state, Nigeria.

\section{Experimental treatments and design}

Treatment consisted of four rice varieties and two moisture regimes (moisture stressed and unstressed environments). The experimental design used was a randomised complete block design with three replicates. The rice varieties ['IR 64', 'IR77298-14-12-B-10' (lowland varieties) and 'WAB56-104', 'NERICA 4' (upland varieties)] possessed different tolerance to soil moisture stress. 'IR 64' was regarded as a highly susceptible rice variety (Venuprasad et al., 2008). 'WAB 56-104' was observed to be moderately tolerant to soil moisture stress. 'IR77298-1412-B-10' and 'NERICA 4' were regarded as highly tolerant varieties to water stress. Before the impositions of soil moisture stress, all rice plants were maintained at full field capacity. Soil moisture stress condition was achieved through withdrawal of water at 7 weeks (49 DAS) after sowing by draining moisture using an adjustable water stopper (drainer). Soil moisture stress was maintained until the most susceptible rice variety ('IR 64') had its leaves fully rolled (rolling score $=9$ ). After cessation of each drought cycle, soil moisture was maintained near field capacity. The next cycle of drought stress was imposed on fully recovered rice plants. Two drought cycles were carried out (at 52 and 75 DAS). In the controlled environment, rice plants were well watered near field capacity throughout the duration of the experiment.

\section{Cultural operations}

Rice seeds were raised in nursery pots. Twenty one day old rice seedlings were transplanted into buckets. The buckets were of $52 \mathrm{~cm}$ wide (diameter) at the surface, $64 \mathrm{~cm}$ deep and 100 litres $\left(100,000 \mathrm{~cm}^{3}\right)$ in volume. Two seedlings per stand were transplanted into the bucket on the $18^{\text {th }}$ April 2014 and later thinned one week after transplanting. Spacing of $20 \mathrm{~cm}$ in a triangular form was adopted in the bucket. The seedlings in the bucket were kept weed free manually. A split application of inorganic fertiliser was adopted. At planting $100 \mathrm{~kg} \mathrm{ha}^{-1}$ of N-P-K (15-15-15) was applied and top dressed with $50 \mathrm{~kg} \mathrm{ha}^{-1}$ of urea $(46 \% \mathrm{~N})$ at 21-30 DAS and $50 \mathrm{~kg} \mathrm{ha}^{-1}$ of urea ( $\left.46 \% \mathrm{~N}\right)$ at $42-50$ DAS. Harvesting was conducted manually at 90\% physiological maturity.

\section{Data collection}

The following parameters were taken: leaf stomata conductance, maximum photosystem II photochemical efficiency (FV/FM), leaf water potential, leaf photosynthetic rate, leaf rolling score, leaf tip drying score, number of dead leaves, leaf area, specific leaf area and grain yield per plant. Leaf stomatal conductance was measured using a steady state leaf porometer (Leaf porometer model SC-1 LPS 1993, Decagon devices, USA). Photochemical efficiency of photosystem II was measured using fluorescence meter (Hansatech Instrument, PPEA 120019, UK). A leaf was dark adapted for 20 minutes in order to obtain the maximum fluorescence signal. Thereafter, 
222

samples were illuminated with continuous red light (wavelength in peak $62 \eta \mathrm{m}$ and the light pulse intensity used was $\left.3,500 \mu \mathrm{mol}^{-2} \mathrm{~s}^{-1}\right)$. Measurement was done on three fully developed leaves and measurement averaged. From the terminal leaflet of the uppermost fully expanded leaf of each plant leaf water potential was measured using pressure chamber (ARIMAD 3000, MRC, UK) as described by (Gindaba et al., 2004). Leaf photosynthetic rate $\left(\mu \mathrm{mol} \mathrm{m}{ }^{-2} \mathrm{~s}\right.$ ${ }^{1}$ ) was measured using Infra-Red Gas Analyzer (Model CI340 Photosynthesis System, CID, Inc., USA). The gas exchange variables were measured under the same environmental conditions. These observations were conducted in situ between 10.00 and 12.00 am in saturating photosynthetic photon flux density $(1,000$ to $1,500 \mathrm{mmol}$ $\mathrm{m}^{-2} \mathrm{~s}^{-1}$ ), with relative humidity that ranged between 45 to $55 \%$ and a leaf temperature of between $28-30^{\circ} \mathrm{C}$, ambient $\mathrm{CO}_{2}$ concentration between $350-450 \mathrm{ppm}$ and the average value of the atmospheric pressure of $760 \mathrm{mmHg}$. Instantaneous measurements were made on four plants per bucket. The measurements were made in each of the three replications of the trial. Leaf rolling score was determined based on the Standard Evaluation System (SES) of rice (IRRI, 2002). A visual score was assigned to indicate the degree of leaf rolling and leaf tip drying based on standard criteria proposed by a SES of rice (IRRI, 2002). Number of dead leaves was counted as leaves that are not photosynthetically active after harvesting visually. Leaf area was measured using a leaf area meter (model LI-3,000C, USA). Specific leaf area was calculated as the leaf area $\left(\mathrm{cm}^{2}\right)$ divided by the oven dry weight of the leaf $(\mathrm{g})$ according the formula suggested by Nageswara et al. (2001). Grain yield per plant was measured as the average weight of the total filled grain per plant.

\section{Field experiment}

Description of location and experimental site

The field trial was conducted at Ikenne (IITA substation) (Latitude $6^{\circ} 52^{\prime} \mathrm{N}$, Longitude $3^{\circ} 43^{\prime} \mathrm{E}$ of about 70 $\mathrm{m}$ a.s.l.), in the rainforest ecology of Nigeria. The soil type is an utisol, with a textural class of clay loam and a $\mathrm{pH}$ range of 4.5-5.4.

\section{Experimental treatments and design}

The treatment consisted of earlier used rice varieties in the open screen house at IITA, Ibadan and two soil moisture regimes (stressed and control). The design was randomised complete block design, replicated three times. All plots were subjected to irrigation from a sprinkler once in three days from planting to 7 weeks after seedling emergence at full field capacity. Soil moisture stress was imposed through withdrawal of irrigation water that commenced from 49 days after sowing till when soil water tension was $-75 \mathrm{kPa}(15 \mathrm{~cm})$ and $-60 \mathrm{kPa}(30 \mathrm{~cm})$ soil depth. Soil water tension was monitored with tensiometer (Model SR 1000, France). The soil was there after re-irrigated untill the soil experienced saturation around root zone. Repeated cycle of soil moisture stress was conducted around flowering to ensure that rice plants sown to soil moisture stressed plot experience approximately 15 days of stress. Control plot was irrigated throughout the growth period except at harvest maturity.

\section{Field cultural operations}

Prior to planting, the field was ploughed and harrowed. The seeds were hand-dibbled at planting. Three seeds were sown at the depth of $2 \mathrm{~cm}$ at a spacing of $20 \times 20 \mathrm{~cm}$. This was later thinned to one hill per stand, three weeks after sowing (WAS). The net plot size measured $1 \times 1 \mathrm{~m}$, which was separated by $0.5 \mathrm{~m}$ between plots. The replicates were separated by $1 \mathrm{~m}$. Basal application of $100 \mathrm{~kg} \mathrm{ha}^{-1}$ of N-P-K (15-15-15) was carried out and top-dressed with $50 \mathrm{~kg} \mathrm{ha}^{-1}$ of urea $(46 \% \mathrm{~N})$ at $21-30$ DAS and $50 \mathrm{~kg} \mathrm{ha}^{-1}$ of urea $(46 \%$ $\mathrm{N}$ ) at 42-50 DAS. The plots were kept weed free manually throughout the duration of the trial. Rain was kept off by using a rain out shelter during raining periods. Birds scarcer were also used to prevent birds from scavenging grains during grain filling.

\section{Sampling and data collection}

Ten hills per net plot were randomly selected. Measurements were taken on leaf stomatal conductance, leaf rolling score, leaf tip drying score, number of dead leaves and leaf water potential as described for the trial in the open screen house. Leaf water potential, leaf relative water content (RWC), stomatal conductance and leaf photosynthetic rate were determined at $58 \mathrm{DAS}$, while number of dead leaves and leaf tip drying score were determined at 59 DAS. RWC content was recorded in the morning hours (8:00 to 9:30 am). Leaf photosynthesis, leaf water potential, stomatal conductance were measured on the same leaf while RWC was measured one flag leaf per hill. Fully expanded flag leaves were sampled and immediately weighed to determine leaf fresh weight (FW). Leaf samples were later placed in sealed plastic bags and water was added. The leaves were hydrated for 24 hours until they became fully turgid, surface dried and reweighed to determine turgid weight (TW). Leaf samples were then oven-dried at $72{ }^{\circ} \mathrm{C}$ for 72 hours and reweighed to determine dry weight (DW). RWC was calculated using the following formula (Barrs and Weatherley, 1962).

$\mathrm{RWC}(\%)=[(\mathrm{FW}-\mathrm{DW}) /(\mathrm{TW}-\mathrm{DW})] \times 100$

Grain yield $\left(\mathrm{kg} \mathrm{ha}^{-1}\right)$ was determined at $90 \%$ harvest maturity.

\section{Statistical analysis}

Data collected were subjected to analysis of variance, fixed model ANOVA for all the factors, at 5\% probability level and significant means were separated using Least Significant Difference (LSD). Discrete data was transformed using square root transformation prior to analysis. The statistical package used was Genstat $12^{\text {th }}$ Edition.

\section{Results}

Physiological and grain yield responses of rice varieties subjected to soil moisture stress (Screen house trial)

Significant $(P<0.05)$ varietal differences were observed on all the foliar characters examined except specific leaf area. Significant leaf area differences among the varieties were in the order 'WAB 56-104' > 'NERICA 4' > 'IR 64' > 'IR 77298-14-1-2-B-10'. A converse pattern was observed on leaf rolling score, where 'WAB 56-104' and 'NERICA 4' 
had significantly the least rolling score, with significantly the highest leaf rolling score recorded for 'IR 64' and 'IR 7729814-1-2-B-10'. Similar pattern was observed on leaf tip dry score and number of dead leaves (Table 1).

Imposition of soil moisture stress had a significant $(P<$ 0.05 ) effect on leaf area, leaf rolling score and number of dead leaves, where rice plant sown in well-watered buckets had significantly higher leaf area than stressed rice plant. Conversely, stressed plant had significantly $(P<0.05)$ higher number of rolled and dead leaves than well-watered control plot (Table 1).

There were no significant varietal differences on all the physiological parameters examined except grain yield per plant and leaf water potential. The most susceptible rice variety ('IR 64') had significantly the lowest leaf water potential $(-11.21 \mathrm{kPa})$, which was followed by 'IR 7729814-1-2-B-10'. 'NERICA 4' (highly tolerant rice variety) had significantly the highest leaf water potential $(-7.94 \mathrm{kPa})$, which was not significantly different from 'WAB 56-104'. Similar pattern was observed on grain yield plant ${ }^{-1}$ (Table 2 ).

There was a significant $(P<0.05)$ effect of the stress status on all the physiological parameters and grain yield per plant. Rice plants sown to well-watered buckets had significantly $(P<0.05)$ higher leaf water potential, photochemical efficiency of photosystem II, stomatal conductance and leaf photosynthetic rate than stressed rice plant. This pattern was also reflected on the grain yield per plant (Table 2).

Table 1. Effect of soil moisture stress on leaf area, specific leaf area, leaf rolling score, leaf tip drying score and numbers of dead leaves of rice varieties in an open screen house experiment

\begin{tabular}{|c|c|c|c|c|c|}
\hline Treatments & $\begin{array}{c}\text { Leaf area } \\
\left(\mathrm{cm}^{2}\right)\end{array}$ & $\begin{array}{l}\text { Specific leaf area } \\
\left(\mathrm{cm}^{2} \mathrm{~g}^{-1}\right)\end{array}$ & $\begin{array}{c}\text { Leaf rolling } \\
\text { score }\end{array}$ & $\begin{array}{l}\text { Leaf tip drying } \\
\text { score }\end{array}$ & $\begin{array}{c}\text { Numbers of dead } \\
\text { leaves }\end{array}$ \\
\hline \multicolumn{6}{|l|}{ Variety } \\
\hline 'IR 64' & 39.77 & 19.40 & 4.00 & 3.28 & 287.6 \\
\hline 'WAB 56-104' & 67.97 & 12.20 & 2.00 & 2.66 & 66.90 \\
\hline 'IR 77298-14-1-2-B-10’ & 35.21 & 12. 80 & 4.00 & 2.74 & 144.70 \\
\hline 'NERICA 4' & 54.03 & 13.10 & 2.00 & 1.54 & 62.60 \\
\hline $\operatorname{LSD}(0.05)$ & $7.88^{* *}$ & $\mathrm{~ns}$ & $0.36^{* *}$ & $0.75^{* *}$ & 2. $20^{* *}$ \\
\hline \multicolumn{6}{|l|}{ Stress status } \\
\hline Stress & 40.88 & 14.0 & 6.0 & 3.92 & 249.0 \\
\hline Control & 57.61 & 14.70 & 0.0 & 1.2 & 31.20 \\
\hline $\operatorname{LSD}(0.05)$ & $5.57^{* *}$ & ns & $0.26^{*}$ & ns & $1.57^{* *}$ \\
\hline \multicolumn{6}{|l|}{ Interaction } \\
\hline \multicolumn{6}{|l|}{ Varieties $\times$ stress status } \\
\hline LSD & $11.14^{*}$ & $17.33^{*}$ & $0.52^{*}$ & ns & $3.14^{* *}$ \\
\hline
\end{tabular}

LSD- Least Significant Differences of means, ns - not significant, ${ }^{*}$ - significant at $5 \%$ level and ${ }^{* *}$ - significant at $1 \%$ level.

Table 2. Effect of soil moisture stress on leaf water potential, maximum quantum yield of photosystem II, stomata conductance, leaf photosynthetic rate and grain yield of rice varieties (open screen house experiment)

\begin{tabular}{|c|c|c|c|c|c|}
\hline Treatments & $\begin{array}{c}\text { Leaf water } \\
\text { potential } \\
(-\mathrm{kPa})\end{array}$ & $\begin{array}{c}\text { Photosystem II photochemical } \\
\text { efficiency } \mathrm{F}_{\mathrm{v}} / \mathrm{F}_{\mathrm{m}} \\
\left(\mu \text { mol photons } \mathrm{m}^{-2} \mathrm{~s}^{-1}\right)\end{array}$ & $\begin{array}{l}\text { Stomatal conductance } \\
\qquad\left(\mathrm{mmolm}^{-2} \mathrm{~s}^{-1}\right)\end{array}$ & $\begin{array}{l}\text { Leaf photosynthetic } \\
\text { rate }\left(\mu \mathrm{molm}^{-2} s^{-1}\right)\end{array}$ & $\begin{array}{l}\text { Grain yield } \\
\left(\mathrm{g} \text { plant }^{-1}\right)\end{array}$ \\
\hline \multicolumn{6}{|l|}{ Variety } \\
\hline 'IR 64' & -11.21 & 0.77 & 486.00 & 12.63 & 130.30 \\
\hline 'WAB 56-104' & -7.94 & 0.79 & 402.00 & 12.83 & 136.50 \\
\hline 'IR 77298-14-1-2-B-10’ & -9.70 & 0.79 & 472.00 & 12.88 & 101.60 \\
\hline 'NERICA 4' & -7.94 & 0.79 & 402.00 & 12.83 & 159.80 \\
\hline $\operatorname{LSD}(0.05)$ & $1.13^{* *}$ & ns & $\mathrm{ns}$ & ns & $38.54^{* *}$ \\
\hline \multicolumn{6}{|l|}{ Stress status } \\
\hline Stressed & -14.83 & 0.76 & 198.0 & 3.83 & 71.5 \\
\hline Control & -3.81 & 0.81 & 684.0 & 21.49 & 192.6 \\
\hline $\operatorname{LSD}(0.05)$ & $0.8^{* *}$ & $0.03^{*}$ & $242.7^{*}$ & $1.12^{* *}$ & $27.25^{* *}$ \\
\hline \multicolumn{6}{|l|}{ Interaction } \\
\hline Varieties $\times$ stress status & $1.60^{* *}$ & $\mathrm{~ns}$ & $342.21^{*}$ & ns & $54.50^{*}$ \\
\hline
\end{tabular}

LSD- Least Significant Differences of means, ns - not significant, ${ }^{*}$ - significant at $5 \%$ level and ${ }^{* *}$ - significant at $1 \%$ level. 
224

Physiological and grain yield responses of rice varieties subjected to soil moisture stress (Field trial)

There was a significant $(P<0.05)$ varietal difference on all the foliar characters examined. 'NERICA 4' had significantly the highest leaf water potential $(-6.25 \mathrm{kPa})$ than other varieties. The least significant leaf water potential $(-10.85 \mathrm{kPa})$ was observed in 'IR 64'. Leaf relative water content significantly $(P<0.05)$ increased with increasing tolerance of varieties to soil moisture stress. Significant decrease in leaf rolling score was in the order 'IR 64' > 'IR 77298-12-1-2-B-10' > 'WAB 56-104' > 'NERICA 4'. Similar pattern was observed on leaf tip dry score and number of dead leaves. The soil stress status had a significant effect on all the foliar characters examined on the field. Rice plants sown to well- watered plots had significantly higher leaf water potential and relative turgidity than those in suboptimal water regime. Conversely rice plants sown in plots that were subjected to soil moisture stress had significantly higher leaf rolling and leaf tip score and more number of dead leaves (Table 3).

Significant varietal differences were observed on stomatal conductance, leaf photosynthetic rate and grain yield. Variety 'IR 64' had significantly the highest stomatal conductance $\left(1,357.13 \mathrm{mmol} \mathrm{m} \mathrm{m}^{-1}\right)$ compared to other varieties, while the least stomatal conductance $(1,106.30$ $\left.\mathrm{mmol} \mathrm{m} \mathrm{s}^{-1}\right)$ was recorded for variety 'IR 77298-12-1-2-B10 '. Leaf photosynthetic rate increased significantly $(P<$ 0.05 ) with increasing tolerance to soil moisture stress in the varieties. Similar pattern was observed on the grain yield. Soil moisture regime significantly $(P<0.05)$ affected all the physiological parameters examined. Rice crop sown to optimal soil moisture regime had significantly higher stomatal conductance, leaf photosynthetic rate and grain yield than those sown under soil moisture stress (Table 4).

Table 3. Effect of soil moisture stress on leaf water potential, leaf rolling score of rice, relative water content and numbers of dead leaves (field condition)

\begin{tabular}{|c|c|c|c|c|c|}
\hline Treatments & $\begin{array}{l}\text { Leaf water potential } \\
\qquad(-\mathrm{kPa})\end{array}$ & $\begin{array}{c}\text { Relative water content } \\
(\%)\end{array}$ & $\begin{array}{l}\text { Leaf rolling } \\
\text { score }\end{array}$ & $\begin{array}{c}\text { Leaf tip drying } \\
\text { score }\end{array}$ & $\begin{array}{l}\text { Numbers of } \\
\text { dead leaves }\end{array}$ \\
\hline \multicolumn{6}{|l|}{ Variety } \\
\hline 'IR 64' & -10.85 & 64.86 & 3.83 & 1.07 & 171.0 \\
\hline 'WAB 56-104' & -6.59 & 72.97 & 1.50 & 0.74 & 54.30 \\
\hline 'IR 77298-14-1-2-B-10' & -7.88 & 72.16 & 2.00 & 0.90 & 65.30 \\
\hline 'NERICA 4' & -6.25 & 73.30 & 1.33 & 0.50 & 47.20 \\
\hline $\operatorname{LSD}(0.05)$ & $0.56^{* *}$ & $2.58^{* *}$ & $0.14^{* *}$ & $0.24^{* *}$ & $1.42^{* *}$ \\
\hline \multicolumn{6}{|l|}{ Stress status } \\
\hline Stress & -13.01 & 50.64 & 4.33 & 1.61 & 146.7 \\
\hline Control & -2.49 & 91.00 & 0.00 & 0.00 & 22.7 \\
\hline $\operatorname{LSD}(0.05)$ & $0.39^{* *}$ & $3.66^{* *}$ & $0.10^{* *}$ & $0.17^{* *}$ & $1.007^{* *}$ \\
\hline \multicolumn{6}{|l|}{ Interaction } \\
\hline Varieties $\times$ stress status & $079^{* *}$ & $5.17^{* *}$ & $0.20^{* *}$ & $0.81^{* *}$ & $60.32^{* *}$ \\
\hline
\end{tabular}

LSD- Least Significant Differences of means, ns - not significant, ${ }^{*}$ - significant at $5 \%$ level and ${ }^{* *}$ - significant at $1 \%$ level.

Table 4. Effect of soil moisture stress on leaf stomatal conductance, leaf photosynthetic rate and grain yield of rice varieties (field condition)

\begin{tabular}{|c|c|c|c|}
\hline Treatments & $\begin{array}{l}\text { Stomatal conductance } \\
\qquad\left(\mathrm{mmol} \mathrm{m}^{-2} \mathrm{~s}^{-1}\right)\end{array}$ & $\begin{array}{l}\text { Leaf photosynthetic rate } \\
\qquad\left(\mu \mathrm{mol} \mathrm{m}^{-2} \mathrm{~s}^{-1}\right)\end{array}$ & $\begin{array}{c}\text { Grain yield } \\
\left(\mathrm{kg} \mathrm{ha}^{-1}\right)\end{array}$ \\
\hline \multicolumn{4}{|l|}{ Varieties } \\
\hline 'IR 64’ & $1,357.13$ & 14.90 & $2,319.0$ \\
\hline 'WAB 56-104' & $1,286.64$ & 15.51 & $4,069.0$ \\
\hline 'IR 77298-14-1-2-B-10' & $1,106.3$ & 15.56 & $3,494.0$ \\
\hline 'NERICA 4' & $1,262.7$ & 16.28 & $4,531.0$ \\
\hline $\operatorname{LSD}(0.05)$ & $79.94^{* *}$ & $0.55^{* *}$ & $923.6^{* *}$ \\
\hline \multicolumn{4}{|l|}{ Stress status } \\
\hline Stress & 155.79 & 8.28 & $2,888.0$ \\
\hline Control & 2350.74 & 22.83 & $4,319.0$ \\
\hline $\operatorname{LSD}(0.05)$ & $56.53^{* *}$ & $0.39^{* *}$ & $653.1^{* *}$ \\
\hline \multicolumn{4}{|l|}{ Interaction } \\
\hline Varieties $\times$ stress status & $113.06^{* *}$ & $\mathrm{~ns}$ & $1,306.20^{*}$ \\
\hline
\end{tabular}




\section{Discussion}

Significant $(P<0.05)$ varietal differences observed among the investigated rice varieties from different production ecologies that differed on their drought tolerance could be premised on their underlying physiological differences. In the screen house, for all the physiological parameters investigated, variety 'WAB 56104 ' had significantly $(P<0.05)$ higher leaf area $\left(67.97 \mathrm{~cm}^{2}\right)$ than other cultivars. This could suggest a higher assimilatory surface for light capture and transpiration. However, all the varieties displayed similar gas exchange properties. The higher assimilatory surface could also have been supported by the morphology of the leaf (more flat leaf and reduced number of dead leaves). Leaf growth in this variety could have been explained by its significantly $(P<0.05)$ higher leaf water potential than other varieties except 'NERICA 4 '. This could have supported a more favourable water and energy balance to maintain leaf growth and carbon assimilatory process. Such an observation was also reported in 'IR 64' rice Near Isogenic lines (NIL) under drought with different combinations of drought yield ( $q D T Y)$ quantitative trait loci (QTL) (Henry et al., 2015b). There was observed that combined $q D T Y$ QTL in 'IR 64' rice NIL under water deficit possessed better root hydraulic conductance, higher leaf water potential, lower canopy temperature and more grain yield than the droughtsusceptible 'IR64'. However, in the screen house gas exchange and photosynthetic efficiency of photosystem II were not significantly different among the rice cultivars despite favourable foliar characters of 'WAB 56-104' and 'NERICA 4' rice compared to others. Studies had earlier indicated that limitation to gas exchange precedes damages to the photosynthetic apparatus (Centritto et al., 2009). Similarities in the gas exchange properties of these varieties could have translated to the similarities observed in the chlorophyll fluorescence parameter. Bączek-Kwinta et al. (2011) opined that the interpretation of chlorophyll fluorescence parameter should be premised on growth stage of the crop, water regimes imposed and the use of other chlorophyll fluorescence parameters to provide a more integrative view of the stress status of the crop concerned. Despite this feature, 'WAB 56-104' and 'NERICA 4' still maintained superior grain yield per plant than other drought susceptible rice varieties. Kumar and Singh (1998) also observed significant varietal differences in oilseed Brassica species. In their own trial, Brassica species with favourable leaf water potential parameters had positive leaf gas exchange parameters (leaf hydraulic conductance, stomatal conductance), which had a significant effect on their seed yield. They opined that the positive leaf water parameters found in some of the varieties they investigated were supported by high osmotic adjustment. This could not be substantiated in the hereby trial. The comparatively more susceptible variety ('IR 64') displayed significantly a reduced leaf area than others. This reduced assimilatory surface could have been exacerbated by the morphology of its leaf (more rolled, with significantly higher number dead and drying leaves). The water status of 'IR 64' was comparatively lower, probably as a strategy to compensate for its susceptibility to adverse environmental condition. On the field, similar physiological response pattern was repeated in 'NERICA 4' and 'IR 64' rice varieties, validating earlier physiological mechanism observed in the screen house. The only exception was the comparatively higher stomatal conductance observed on the field in 'IR 64'. This could have predisposed the variety to a change in water balance through increased water loss under reduced supply. Stomatal conductance is a component of the total diffusion that involves mesophyll diffusion. Proper interpretation could be better done when examined in the context of other mechanisms (dehydration avoidance and escape mechanism), together with its leaf water potential. Serraj $e t$ al. (2008) had earlier opined that rice is better described as dehydration avoider, the significantly higher stomatal conductance observed in 'IR 64' on the field could be a disadvantage towards drought tolerance.

In the screen house, significantly lower leaf area was observed in the repeated cycle of water stress at reproductive growth stage than unstressed rice. This was also observed on the significantly reduced leaf water potential of stressed rice plant than unstressed. This would have affected the leaf water balance and its consequent effect on the morphology the leaf. Demirevska et al. (2008) observed a significant reduction in tissue RWC with increasing severity of drought. Reduced cellular turgidity implied with reduced water potential would have suggested a disruption in the structural integrity of the leaf cells, through electrolyte leakage (Faroog et al., 2012). This could partly explain the observed significant increase in the number of dead leaves in rice sown to plots subjected to soil moisture stress. With the disruption in water balance and changes in leaf morphology, other physiological processes (transpiration and photosynthesis) are expected to be negatively affected. It had been reported that soil moisture stress affects water status of plant through the components of water potential (Chakraborty et al., 2008). Reduced turgor potential in the absence of osmoregulation or elastic properties of the cell would alter the morphology of the leaf. Stressed rice plants were observed to be rolled, which could have explained their increasing xeromorphism. Similar observation was indicated by O'Toole and Cruz (1980) when rice plant was subjected to soil water moisture, especially the abaxial leaf surface. Rolled leaf under soil moisture stress had also been observed to reduce leaf angle and increased reflexibility of radiant energy. This could reduce the amount of light intercepted (Heckathorn and DeLucia, 1991) and photoinhibition (Lebkuecher and Eichneier, 1990) when crops are subjected to soil moisture stress. They also observed that reduced amount of intercepted radiant energy would positively affect energy balance through reduced leaf temperature and leaf-air water vapour deficit. In the present trial, it was observed that though stressed rice plants exhibited earlier corroborated findings the efficiency of photosystem II was compromised, despite the positive effect rolled leaves could have conferred on leaf energy balance. The magnitude of the leaf rolling, the leaf surface where it was most predominant and other environmental factors could have exacerbated efficiency of leaf photochemistry under soil water deficit. With rolled leaves significant reduction was observed in the stomatal conductance of rice plants, which would have constrained water vapour and gas exchange (Parker, 1968; Araus et al., 2002). With increased diffusional constraint 
226

there was observed reduced leaf photosynthetic rate and grain yield. Izanloo et al. (2008) noticed positive effect of leaf stomatal conductance on grain yield in rice, wheat and cotton under soil moisture stress. Irrigation was stopped at the reproductive growth stage. Lilley and Fukai (1994) reported that yield and yield components are negatively correlated with stress at reproductive growth stage. Increased number of dead leaves with rolled leaves could also have compounded the reduced photosynthetic rate observed through reduced assimilatory surface (Begg et al., 1980) and consequently interception of radiant energy. A compromised water balance and other hydraulic properties of rice plant must have explained significantly higher numbers of dead leaves in moisture stressed rice plants than those grown in optimal soil moisture regime. It was observed that failure of hydraulic properties of leaf initiates senescence (Holbrook et al., 2001). Ferrio et al. (2012) observed that leaf hydraulic conductance reduces with drought. Translocation of assimilates is mediated by pressure gradient (Sheikholeslam and Currier, 1977; Lang, 1983). Blum and Arkin (1984) were of the opinion that increased number of dead leaves especially in older leaves in some crop could be a mechanism to reduce waster loss. On the field soil moisture withdrawal through cessation of irrigation indicated that the soil had significantly lower water potential $(-50 \mathrm{kPa})$ than the plots sown to rice with optimal water regime $(-16 \mathrm{kPa})$. The physiological responses observed in the screen house under repeated cycle of water deficit at reproductive growth stage in rice from different production ecologies were validated on the field despite the fact that the number of drought cycles was lesser than those simulated in the screen house. This could have suggested that the intensity of water deficit might have played lesser role than the initiation of it at this growth stage.

\section{Conclusions}

The findings from both trials supported the hypothesis that repeated cycles of water deficit at reproductive growth stage resulted in significant differences among the rice varieties from different production ecologies. The physiological mechanism that underpins these differences with respect to water deficit at the investigated growth stage was more balanced water status, improved foliar characters, efficient photosynthetic capacity and grain yield in comparatively drought tolerant upland rice varieties ('NERICA 4' and 'WAB 56-104') compared with drought susceptible one ('IR 64'). In both trials, repeated cycles of water deficit at the reproductive growth stage resulted in significant reduction in assimilatory surface, with lower leaf water potential than for the unstressed rice varieties. Rice varieties subjected to repeated cycle of water deficit at this growth stage were more prone to photoinhibition, with significantly reduced photosynthetic capacity through diffusive constraint on water vapour and carbon dioxide influx. The obtained results were validated on the field despite the reduced number of water stress cycles experienced. Such data could have suggested that the initiation of water deficit is the rate limiting step rather than the intensity of water deficit at grain filling stage in rice from different production ecologies.

\section{Acknowledgements}

Our profound appreciation goes to the staff of AfricaRice for accepting Miss Mauton Popogbe to conduct her MSc research programme in their premises and allowing her use their facilities.

\section{References}

Araus JL, Slafer GA, Reynolds MP, Royo C (2002). Plant breeding and drought in $\mathrm{C} 3$ cereals: what should we breed for? Annals of Botany 89(7):925-940.

Araus JL, Slafer GA, Reynolds MP, Royo C (2002). Plant breeding and drought in $\mathrm{C} 3$ cereals: what should we breed for? Annals of Botany 89(7):925-940.

Baczek-Kwinta R, Kozie A, Seidler-Lożykowska K (2011). Are the fluorescence parameters of German chamomile leaves the first indicators of the anthodia yield in drought conditions? Photosynthetica 49(1):8797.

Barrs HD, Weatherley PE (1962). A re-examination of the relative turgidity technique for estimating water deficits in leaves. Australian Journal of Biological Sciences 15(3):413-428.

Begg JE, Turner NC, Kramer PJ (1980). Morphological adaptations of leaves to water stress. Adaptation of Plants to Water and High Temperature Stress $33-42$.

Blum A, Arkin GF (1984). Sorghtum root growth and water-use as affected bywater supply and growth duration. Field Crops Research 9:131-142.

Centritto M, Lauteri M, Monteverdi MC, Serraj R (2009). Leaf gas exchange, carbon isotope discrimination, and grain yield in contrasting rice genotypes subjected to water deficits during the reproductive stage. Journal of Experimental Botany 60(8):2325-2339.

Chakraborty D, Nagarajan S, Aggarwal P, Gupta V K, Tomar RK, Garg $\mathrm{RN}$, Kalra N (2008). Effect of mulching on soil and plant water status, and the growth and yield of wheat (Triticum aestivum $\mathrm{L}$.) in a semi-arid environment. Agricultural Water Management 95(12):1323-1334.

Demirevska K, Simova-Stoilova L, Vassileva V, Feller U (2008). Rubisco and some chaperone protein responses to water stress and rewatering at early seedling growth of drought sensitive and tolerant wheat varieties. Plant Growth Regulation 56(2):97-106.

Diagana B, AkindesF, Savadogo K, Reardon T, StaatzJ (1999). Effects of the CFA franc devaluation on urban food consumption in West Africa: overview and cross-country comparisons. Food Policy 24(5):465-478.

Diagne A, Alia D, Amovin-Assagba E, Wopereis MC, Saito K, Nakelse T (2013). Farmer perception of biophysical constraints to rice production in sub-Sahara Africa and potential impact of research. In: Realising Africa rice promise. Nosworthy way, Wallingford, Oxfordshire OX 10 8DE, UK: CABI pp 46-68.

Farooq M, Hussein M, Wahid A, Siddique KH (2012). Plant responses to drought stress. Berlin, Heidellberg: Springer.

Ferrio JP, Pou A, Florez-sarasa I, Gessler A, Kodama N, FlexasJ, Ribas-carbo M(2012). The Péclet effect on leaf water enrichment correlates with leat hydraulic conductance and mesophyll conductance for $\mathrm{CO}_{2}$. Plant, Cell and Environment 35(3):611-625. 
Gindaba J, Rozanov A, Negash L (2004). Response of seedlings of two Eucalyptus and three deciduous tree species from Ethiopia to severe water stress. ForestEcology and Management 201(1):119-129.

Grzesiak MT, Janowiak F, Szczyrek P, Kaczanowska K, Ostrowska A, Rut G, Grzesiak S (2016). Impact of soil compaction stress combined with drought or waterlogging on physiological and biochemical markers in two maize hybrids. Acta Physiologiae Plantarum 38(5):1-15.

Heckathorn SA, DeLucia EH (1991). Effect of leaf rolling on gas exchange and leaf temperature of Andropogon gerardii and Spartina pectinata. Botanical Gazette 152(3):263-268.

Henry A, Cal AJ, Batoto TC, Torres RO, Serraj R (2012). Root attributes affecting water uptake of rice (Oryza sativa) under drought. Journal of Experimental Botany 63(13):4751-4763.

Henry A, Swamy BM, Dixit S, Torres RD, Batoto TC, Manalili M, Kumar A (2015). Physiological mechanisms contributing to the QTLcombination effects on improved performance of IR64 rice NILs under drought. Journal of Experimental Botany 66(7):1787-1799.

Holbrook NM, Ahrens ET, Burns MJ, Zwieniecki MA (2001). In vivo observation of cavitation and embolism repair using magnetic resonance imaging. Plant Physiology 126(1):27-31.

Idris A, Rasaki K, Hodefe OJ, Hakeem B (2013). Consumption pattern of Ofada rice among civil servants in Abeokuta Metropolis of Ogun State, Nigeria.Journal of Biology, Agriculture and Healthcare 3(6):106-112.

IRRI (2002). Standard evaluation system for rice. International Rice Research Institute, Philippine.

Izanloo A, Condon AG, Langridge P, Tester M, Schnurbusch T (2008). Different mechanisms of adaptation to cyclic water stress in two South Australian bread wheat cultivars. Journal of Experimental Botany 59(12):3327-3346.

Jones MP, Dingkuhn M, Aluko GK, Semon M (1997). Interspecific Oryza sativa L. 0 . glaberrima Steud. progenies in upland rice improvement. Euphytica 94(2):237-246.

Kumar A, Singh DP (1998). Use of physiological indices as a screening technique for drought tolerance in oilseed Brassica species. Annals of Botany 81(3):413-420.

Lang A (1983). Turgor-regulated translocation. Plant, Cell and Environment 6(9):683-689.
Lebkuecher J, Eichneier W (1990). Dessication-induced plant curling and high-irradiance damage in the desert resurrections plant Seaginella lepidophylla. Bulletin of Ecological Society of America 71:227.

Lilley JM, Fukai S (1994). Effect of timing and severity of water deficit on four diverse rice cultivars I. Rooting pattern and soil water extraction. Field Crops Research 37(3):205-213.

Nageswara Rao RC, Talwar HS, Wright GC (2001). Rapid assessment of specific leaf area and leaf nitrogen in peanut (Arachis hypogaea L.) using a chlorophyll meter.Journal of Agronomy and Crop Science 186(3):175182.

O'Toole JC, Cruz RT (1980). Response of leaf water potential, stomatal resistance, and leaf rolling to water stress. Plant Physiology 65(3):428432.

Parker J (1968). Drought- resistance mechanisms. In: Kozlowski T (Ed) (Vol. 1).New York: Academic Press.

Parry ML (2007). Climate Change 2007: impacts, adaptation and vulnerability: contribution of Working Group II to the fourth assessment report of the Intergovernmental Panel on Climate Change (Vol.4). Cambridge University Press.

Serraj R, Dimayuga D, Gowda V, Guan Y, Hong He, Impa S, Torres R (2008). Drought resistant rice: physiological framework for integrated research strategy. In: Serraj R, BennettJ, Hardy B(Eds). World Scientific Publishing.

Sheikholeslam SN, Currier HB (1977). Effect of water stress on turgor differences and 14C-assimilate movement in phloem of Ecballium elaterium. Plant Physiology 59(3):381-383.

Tardieu F (2013). Plant response to environmental conditions: assessing potential production, water demand and negative effects of water deficit. Frontiers in Physiology 4:1-17.

Venuprasad R, Cruz MS, Amante M, Magbanua R, Kumar A, Atlin GN (2008). Response to two cycles of divergent selection for grain yield under drought stress in four rice breeding populations. Field Crops Research 107(3):232-244.

Wopereis MCS, Diagne A, Rodenburg J, Sié M, Somado EA (2008). Why NERICA is a successful innovation for African farmers: A response to Orr et al. from the Africa Rice Center. Outlook on Agriculture 37(3):169-176. 